\title{
PRIMARY AND SECONDARY RESIDENTIAL REAL ESTATE MARKETS IN POLAND - ANALOGIES IN OFFER AND TRANSACTION PRICE DEVELOPMENT
}

\author{
Iwona Dittmann, Ph.D \\ Faculty of Finance \\ University of Economics in Wroctaw \\ e-mail: iwona.dittmann@ue.wroc.pl
}

\begin{abstract}
The paper presents the results of a comparison of the development of mean offer and transaction prices per $1 \mathrm{~m}^{2}$ in primary and secondary residential real estate markets in 16 provincial capital cities in Poland, during the time period from the 3rd quarter of 2006 to the 3rd quarter of 2012. The quarterly data came from the residential real estate price database of the National Bank of Poland (NBP). The research concerns the dependencies in the residential real estate market between the following four price categories: offer prices in the primary market, transaction prices in the primary market, offer prices in the secondary market and transaction prices in the secondary market. For each city, the dynamics of each price category per $1 \mathrm{~m}^{2}$, the existence of a linear correlation between the individual mean price categories in chosen subintervals and their convergence and variability in time were studied and compared.
\end{abstract}

Keywords: residential real estate, primary and secondary markets, offer and transaction prices, comparative analysis.

JEL Classification: R31, Y10.

Citation: Dittmann I., (2013), "Primary and secondary residential real estate markets in Poland analogies in offer and transaction price development", Real Estate Management and Valuation, vol. 21 , no. 1, pp. 39-48.

DOI: 10.2478/remav-2013-0006.

\section{Introduction}

Knowledge of the economics of the real estate market is crucial for investing in real estate. In order to make investment decisions, it is not enough to analyze previous trends in the local market, but it is also necessary to possess knowledge about the principles that rule the market. The basic real estate market rules, such as the law of supply and demand and the characteristics of the market, are wellunderstood and well-described (for example. KUCHARSKA-STASIAK 2012, BRYX 2008, FORYŚ 2011). Research focuses, among other things, on identifying the interdependencies that exist in the real estate market and between the real estate market and other markets, as well as on the variation and variability of prices and price interdependency. It is also concerned with the changes that occur in the real estate market that are connected with its development and functioning in different economic conditions. The similarity of development between local markets has also been studied (for example: AuguSTYNIAK et al. 2012, BALDOWSKA et al. 2012, BEŁEJ 2012, DĄBROWSKI 2009, DĄBROWSKI 2011, GDAKowicz, Hozer 2012, NyKiel 2011, Renigier-BiŁOZOR 2011, TrojaneK 2011, TrOjANeK 2012, ŻELAZOWSKI 2011).

In the following article, the question of similarities between local markets was connected with the 
question of internal variability of the individual markets. Therefore, primary and secondary markets, as well as offer and transaction prices were differentiated. It was decided that such a perspective allowed for a better description of the real estate market than an aggregated perspective.

The results of the study presented within this article are a continuation of an earlier analysis concerning the formation of mean transaction and offer prices per $1 \mathrm{~m}^{2}$ in primary and secondary markets in 14 provincial capitals in Poland (DITTMANN 2013a). The following issues were considered: 1) the existence of certain tendencies in the development of mean transaction and offer prices in primary and secondary markets during the time period between the $3^{\text {rd }}$ quarter of 2006 and the $4^{\text {th }}$ quarter of 2011,2) the variability of mean transaction and offer prices during the studied period in both segments of the residential market 3) the relationship between the levels of mean transaction price and mean offer price, and the price levels in primary and secondary markets in individual cities, and 4) the existence and strength of the dependency between the mean prices per $1 \mathrm{~m}^{2}$ in chosen segments of the residential market. The following were used as tools in this study: price relation measures, variability coefficients and linear correlation coefficients. The source of the empirical material was quarterly data concerning the formation of the mean price per $1 \mathrm{~m}^{2}$ in primary and secondary markets, sourced from the residential real estate price database of the NBP.

This article contains an attempt at verifying the following study hypotheses:

1) Mean prices in the primary market are higher and more subject to change than in the secondary market.

2) Mean transaction prices are more subject to change than mean offer prices.

3) A correlation between the different mean price categories in the studied time period and its subintervals exists.

4) The variability of mean transaction and offer prices in both segments of the residential real estate market in the individual cities decreased over time.

This article also attempts to answer the two following study questions:

1) Did the mean prices in the primary and secondary markets converge during the studied time period or its subintervals?

2) Did the mean offer and transaction prices converge during the studied time period or its subintervals?

The source for the statistical data was the residential real estate price database of the National Bank of Poland (NBP) for 16 provincial capital cities that encompasses the time period from the 3rd quarter of 2006 to the 3rd quarter of 2012. The data has been presented in the form of figures (fig.1). Based on this data and its subparts, the appropriate statistical parameters were calculated.
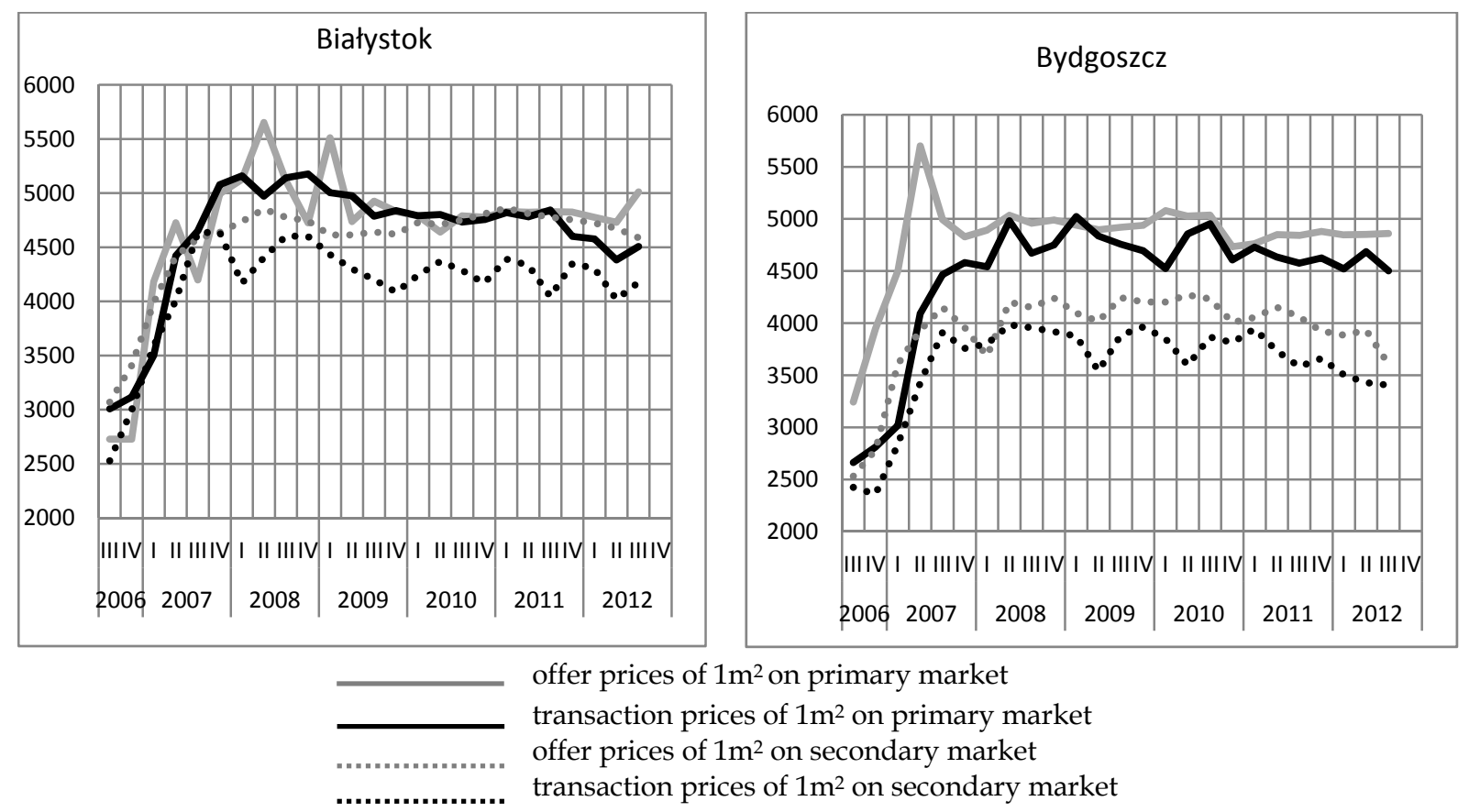


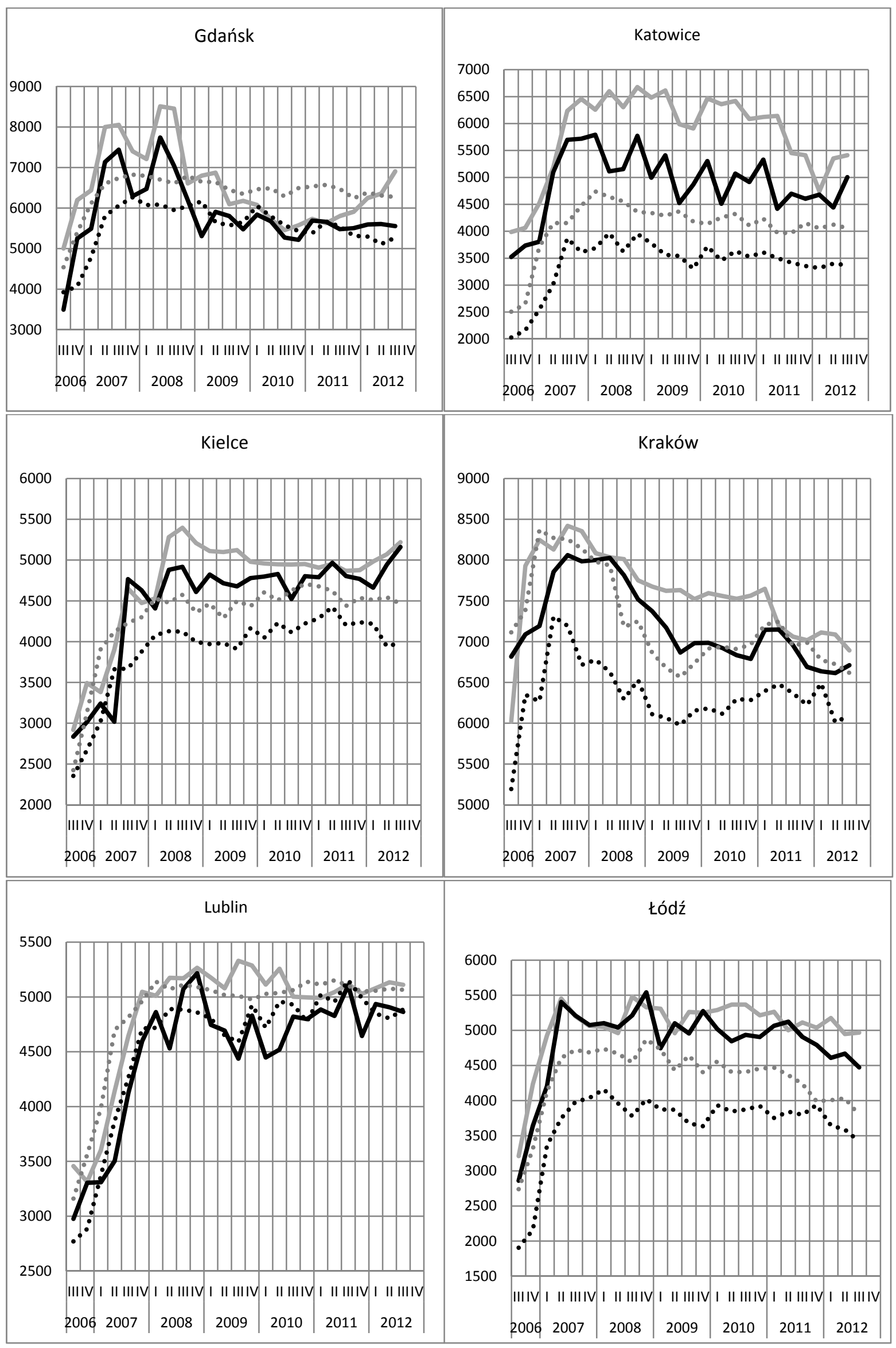




\section{VERSITA}

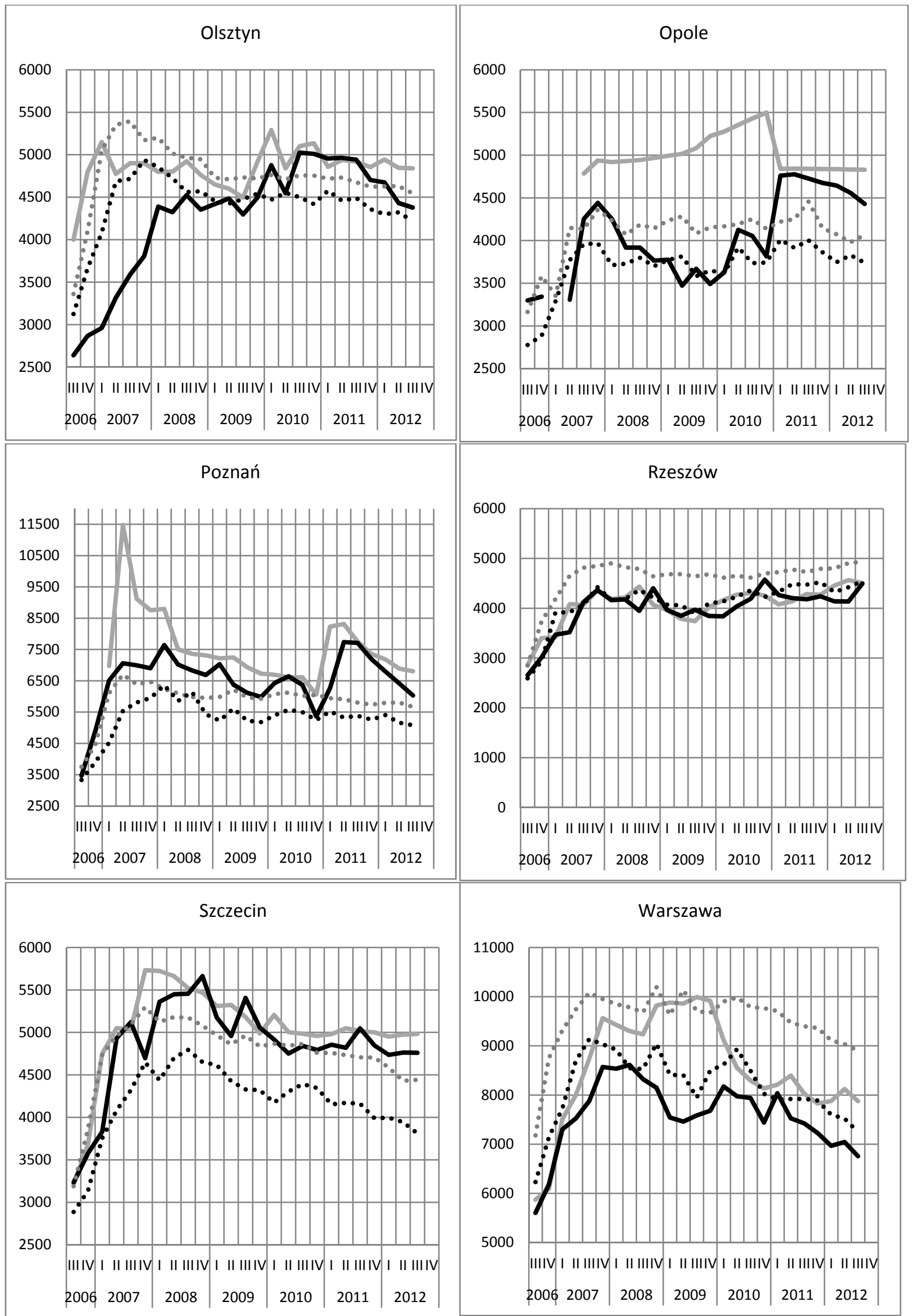




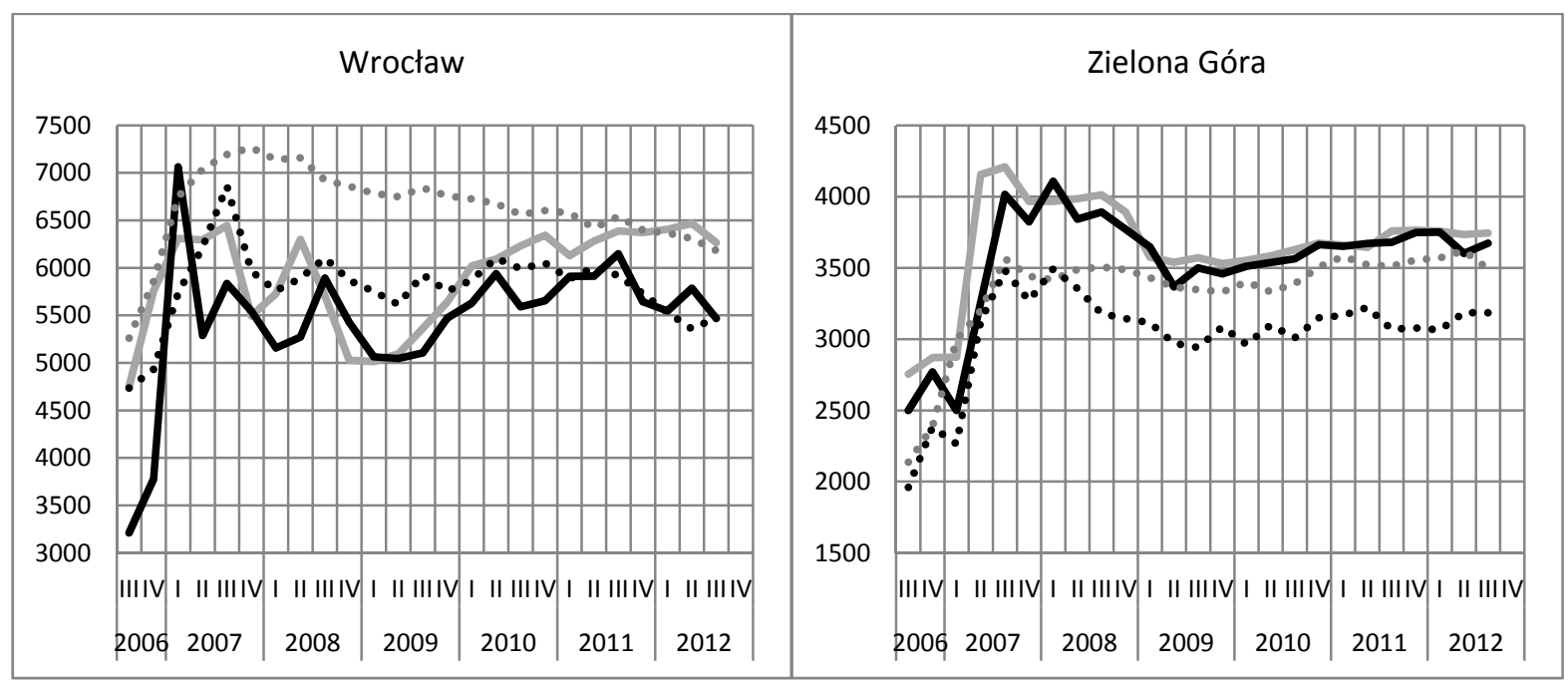

Fig. 1. Mean prices of $1 \mathrm{~m}^{2}$ of living space (PLN). Source: own work, based on (Baza...).

\section{Dynamics of mean prices - a comparison}

In order to study the dynamics of mean prices for each of the 16 cities, the (chain) increase rate was calculated for the following studied price categories: offer prices in the primary market, transaction prices in the primary market, offer prices in the secondary market and transaction prices in the secondary market. Then plots were prepared for these categories. In this article the plots prepared for Wrocław are included as an example (fig. 2). The plots prepared for different cities differed significantly from each other.

In the case of comparing the dynamics of offer prices in the primary and secondary markets, it was found that relationships that agreed with the posed hypothesis (i.e., that the primary market is more dynamic) occurred in the following cities: Białystok, Gdańsk, Katowice, Lublin, Olsztyn, Poznań, Rzeszów, Szczecin and Wrocław. However, in Bydgoszcz, Opole and Kraków, the changes in offer prices in the secondary market were more dynamic. In other cities, there was a lack of a clear (unambiguous) relationship. An analogous analysis of transaction prices revealed the prices in the primary market to be generally more dynamic than in the secondary market in Gdańsk, Katowice, Kielce, Lublin, Olsztyn, Opole, Poznań, Rzeszów, Szczecin and Wrocław. The opposite was observed in Białystok, Kraków and Zielona Góra. There were also cities in which the relationship in the quarters at the beginning of the analyzed time period was opposite of that observed in the later quarters.

When comparing the dynamics of transaction prices with the dynamics of offer prices in the primary market, it was established that the following cities were characterized by greater changes in transaction prices than in offer prices: Bydgoszcz, Gdańsk, Katowice, Kielce, Kraków, Lublin, Olsztyn, Opole, Poznań and Szczecin. Only in Białystok could one notice significantly more distinct changes in offer prices than in transaction prices. In the remaining cities, the dynamics of both price categories were comparable. An analogous comparison for the secondary market led to the conclusion that transaction prices were more subject to change than offer prices (in a significant majority of the analyzed quarters), as was the case in the following cities: Białystok, Bydgoszcz, Gdańsk, Katowice, Kielce (apart from the first 8 quarters), Lublin, Łódź, Olsztyn, Poznań, Rzeszów, Szczecin, and Wrocław. The opposite relationship was not observed. In the case of Warsaw, Opole, Kraków and Zielona Góra the dynamics of both price categories were at comparable levels.

It is worth noting that prices changed more and were higher in the early quarters of the studied period after which they decreased (although in some cities, another noticeable increase took place). 


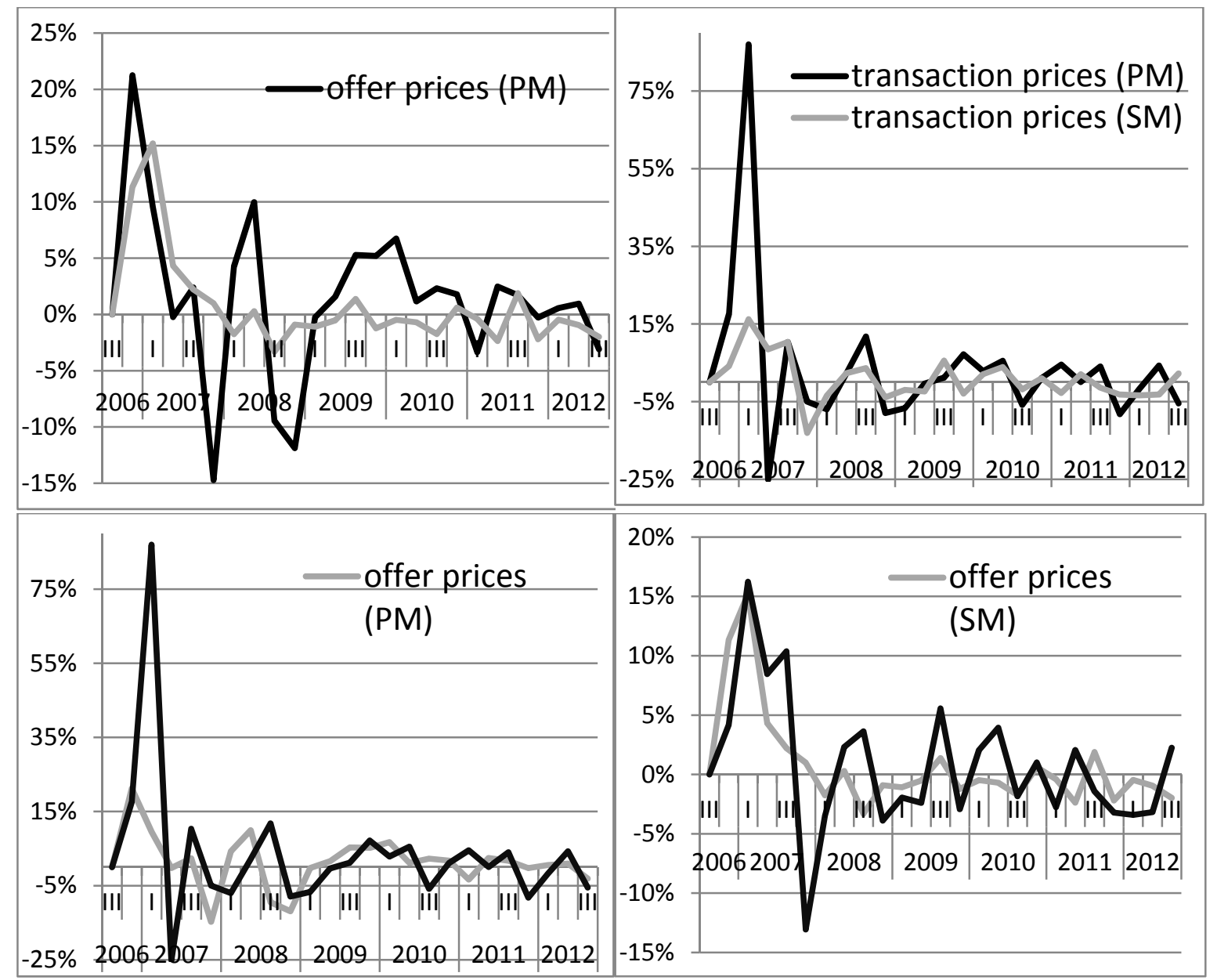

Fig. 2. Chain increase rate (\%) of mean prices of $1 \mathrm{~m}^{2}$ of living space in Wrocław. Source: own work.

\section{Correlation dependency of prices}

The next stage of the study was an evaluation of the existence of a correlation dependence between the different categories of mean prices. In order to obtain a more detailed analysis, it was decided to calculate correlation coefficients for 4 time intervals of different lengths: $A$ - the longest, encompassing the entire studied time period (i.e., from the $3^{\text {rd }}$ quarter of 2006 to the $3^{\text {rd }}$ quarter of 2012$)^{1}, B$ - from the $1^{\text {st }}$ quarter of 2009 to the $3^{\text {rd }}$ quarter of 2012; C - from the 1st quarter of 2010 to the 3rd quarter of 2012 and $D$ - from the 1st quarter of 2011 to the 3rd quarter of 2012. The results have been presented in table 1. Statistically significant coefficients are marked in bold $(\alpha=0.05)$.

Based on the obtained results, it was possible to draw the following conclusions. First, in the case of almost all of the cities, the correlation coefficients calculated for the longest 25-quarter interval (A) point to the existence of strong dependencies between all of the studied price categories. The exceptions to this are Olsztyn, Opole, Poznań and (partly) Wrocław and Gdańsk. On the other hand, in the shorter time intervals (B, C, D), a linear dependency occurs less frequently and is generally weaker. This can be observed in Warsaw, Bydgoszcz (but only between offer and transaction prices in the secondary market), Gdańsk (similarly to Bydgoszcz), Kraków (between offer and transaction prices in the primary and secondary markets), Kielce (only between offer and transaction prices in the primary market), Łódź (apart from the relationship between offer and transaction prices in the primary market), Olsztyn, Opole (between offer prices in the primary and secondary markets), Poznań (like in Kraków - between offer and transaction prices in the primary and secondary markets) Rzeszów (apart from the relationship between offer and transaction prices in the primary market), Szczecin (between offer and transaction prices in the secondary market), Wrocław (like in Szczecin)

\footnotetext{
${ }^{1}$ Due to incomplete data, for Opole and Poznań the time period A is defined to be from the Q3, 2007 - Q3, 2012 (for Opole) and from Q1, 2007 - Q1, 2012 (for Poznań).
} 
and Zielona Góra (apart from relationships between transaction prices in the primary and secondary markets).

Secondly, it may be noticed that in the case of time intervals B, C and D a linear correlation occurred most often in the secondary market between offer and transaction prices.

In summary, it can be concluded that a linear correlation does exist in the chosen subintervals of the analyzed time series. Additional calculations of the correlation coefficient performed for other subintervals (Q3, 2006 - Q1, 2010, Q3, 2007 - Q1, 2010, Q3, 2008 - Q1, 2010), which were not included in this article, confirm this conclusion. These calculations also show an almost universally occurring linear correlation in quarters where prices tended to increase (the boom from 2006 to Q2, 2007). In the following quarters it was possible to observe a continuing existence of this correlation (e.g., in the case of prices in Kraków and Zielona Góra) or the disappearance of a linear correlation between the individual price categories (e.g., in the case of prices in Bydgoszcz or Warsaw).

Table 1

Correlation coefficients

\begin{tabular}{|c|c|c|c|c|c|c|c|c|c|c|c|c|c|c|c|c|}
\hline \multirow[t]{2}{*}{ Cities } & \multicolumn{4}{|c|}{$\begin{array}{l}\text { Primary market: offer prices and } \\
\text { transaction prices }\end{array}$} & \multicolumn{4}{|c|}{$\begin{array}{l}\text { Secondary market: offer } \\
\text { prices and transaction } \\
\text { prices }\end{array}$} & \multicolumn{4}{|c|}{$\begin{array}{l}\text { Transaction prices: secondary } \\
\text { market and primary market }\end{array}$} & \multicolumn{4}{|c|}{$\begin{array}{l}\text { Offer prices: secondary } \\
\text { market and primary market }\end{array}$} \\
\hline & $\mathrm{A}$ & $\bar{B}$ & $\mathrm{C}$ & $\mathrm{D}$ & $\mathrm{A}$ & B & $\mathrm{C}$ & $\mathrm{D}$ & $\bar{A}$ & B & C & $\mathrm{D}$ & $\mathrm{A}$ & $\mathrm{B}$ & C & $\mathrm{D}$ \\
\hline Białystok & 0.88 & 0.32 & -0.21 & 0.04 & 0.92 & 0.18 & 0.36 & 0.51 & 0.92 & 0.40 & 0.38 & 0.37 & 0.90 & -0.39 & -0.26 & -0.44 \\
\hline Bydgoszcz & 0.75 & 0.37 & 0.37 & -0.55 & 0.91 & 0.67 & 0.63 & 0.68 & 0.92 & 0.36 & 0.36 & 0.66 & 0.85 & 0.54 & 0.53 & -0.37 \\
\hline Gdańsk & 0.88 & 0.26 & 0.33 & -0.22 & 0.91 & 0.61 & 0.51 & 0.77 & 0.69 & 0.06 & 0.35 & 0.08 & 0.50 & 0.12 & -0.49 & -0.71 \\
\hline Kielce & 0.94 & 0.39 & 0.67 & 0.78 & 0.95 & 0.46 & 0.31 & 0.52 & 0.87 & -0.01 & -0.21 & -0.44 & 0.86 & -0.44 & -0.27 & -0.28 \\
\hline Kraków & 0.75 & 0.60 & 0.51 & 0.67 & 0.68 & 0.71 & 0.59 & 0.64 & 0.69 & 0.04 & 0.44 & 0.59 & 0.67 & 0.05 & 0.46 & 0.69 \\
\hline Lublin & 0.92 & -0.41 & -0.29 & 0.53 & 0.96 & 0.40 & 0.23 & 0.38 & 0.94 & 0.60 & 0.45 & 0.29 & 0.94 & -0.67 & -0.52 & -0.29 \\
\hline Łódź & 0.89 & 0.25 & 0.43 & 0.38 & 0.90 & 0.55 & 0.72 & 0.56 & 0.91 & 0.43 & 0.75 & 0.74 & 0.85 & 0.65 & 0.73 & 0.55 \\
\hline Olsztyn & 0.45 & 0.73 & 0.57 & 0.57 & 0.89 & 0.79 & 0.80 & 0.90 & 0.53 & 0.33 & 0.64 & 0.90 & 0.55 & 0.21 & 0.68 & 0.47 \\
\hline Opole & -0.59 & -0.67 & -0.89 & 0.99 & 0.5 & 0.51 & 0.52 & 0.79 & 0.68 & 0.71 & 0.71 & 0.78 & 0.03 & 0.03 & 0.07 & 0.74 \\
\hline Wrocław & 0.60 & 0.81 & -0.03 & -0.09 & 0.80 & 0.51 & 0.80 & 0.77 & 0.63 & 0.31 & 0.43 & 0.70 & 0.12 & -0.76 & -0.66 & -0.33 \\
\hline Zielona G. & 0.88 & 0.84 & 0.83 & 0.42 & 0.87 & 0.62 & 0.53 & 0.00 & 0.95 & 0.56 & 0.35 & -0.72 & 0.79 & 0.83 & 0.73 & -0.04 \\
\hline
\end{tabular}

Source: own calculations.

\section{Variability and convergence of mean prices}

Another hypothesis that was posed was that the variability of mean transaction and offer prices in both market segments in the studied interval decreased over time in the individual cities. For this purpose, price variability coefficients were calculated for time intervals $\mathrm{A}, \mathrm{B}, \mathrm{C}$ and $\mathrm{D}$. The values of variability coefficients in table 2 seem to confirm the above hypothesis (the values for the longest time period are in bold). In almost all of the cities the largest values of variability coefficients can be observed for prices from the longest interval (A), i.e., Q3 2006 - Q3 2012. The exceptions to this are Opole and partly Poznań (in the case of transaction prices in the primary market). The values of the variability coefficient for this period show that moderate variation existed for offer prices in the primary market, transaction prices in the primary market, offer prices in the secondary market and transaction prices in the secondary market. For the shorter studied subintervals $(\mathrm{B}, \mathrm{C}, \mathrm{D})$, the variability coefficients had lower values, indicating either very low variation or its total absence. This points to the stabilization of prices in individual markets after an earlier boom and subsequent price decreases.

However, it is hard to point to a mean price category that has the greatest variability. First, the situation is different in the individual cities. For example, in the case of Wrocław, the transaction prices in the primary market are characterized by the greatest variability, while in Gdańsk this is true of the offer prices in the primary market and in Łódź - the prices in the secondary market. Second, differences in variability that characterize individual price categories do not seem to be significant in the case of some cities (e.g., Białystok, Lublin, Kraków, Rzeszów). For example, it is possible to observe that prices in the primary market showed only somewhat greater variation than those in the secondary market. 
The last stage of the study was answering the question concerning the existence of a convergence (or divergence) of mean prices per $1 \mathrm{~m}^{2}$ in the primary and secondary markets, and the convergence of offer and transaction prices in the studied interval. In order to answer this question, the variability coefficient was calculated. The values of these coefficients for Wrocław have been presented in figure 3.

Table 2

Variability coefficients (\%)

\begin{tabular}{|c|c|c|c|c|c|c|c|c|c|c|c|c|c|c|c|c|}
\hline \multirow[t]{2}{*}{ Cities } & \multicolumn{4}{|c|}{$\begin{array}{c}\text { Primary market, } \\
\text { offer prices }\end{array}$} & \multicolumn{4}{|c|}{$\begin{array}{l}\text { Primary market, } \\
\text { transaction prices }\end{array}$} & \multicolumn{4}{|c|}{$\begin{array}{c}\text { Secondary market, } \\
\text { offer prices }\end{array}$} & \multicolumn{4}{|c|}{$\begin{array}{l}\text { Secondary market, } \\
\text { transaction prices }\end{array}$} \\
\hline & $\bar{A}$ & $\mathrm{~B}$ & $\mathrm{C}$ & $\mathrm{D}$ & $\mathrm{A}$ & B & $\bar{C}$ & $\mathrm{D}$ & $\mathrm{A}$ & $\mathrm{B}$ & $\mathrm{C}$ & $\mathrm{D}$ & $\mathrm{A}$ & B & $\mathrm{C}$ & $\mathrm{D}$ \\
\hline Warszawa & 12.6 & 9.3 & 4.3 & 2.4 & 9.2 & 5.2 & 6.1 & 5.4 & 6.3 & 3.6 & 3.7 & 2.8 & 8.3 & 5.5 & 5.9 & 3.2 \\
\hline Białystok & 13.9 & 4.0 & 1.8 & 1.7 & 12.2 & 3.4 & 3.1 & 3.5 & 9.4 & 1.7 & 1.5 & 1.8 & 11.4 & 2.9 & 2.9 & 3.3 \\
\hline Bydgoszcz & 8.8 & 1.9 & 2.2 & 0.7 & 14.1 & 3.3 & 2.9 & 1.7 & 10.7 & 4.2 & 4.5 & 4.1 & 12.1 & 5.0 & 4.8 & 4.9 \\
\hline Gdańsk & 14.3 & 7.5 & 6.8 & 6.9 & 14.4 & 3.5 & 3.1 & 1.3 & 7.4 & 2.0 & 1.7 & 1.9 & 10.4 & 5.0 & 4.7 & 3.2 \\
\hline Katowice & 13.4 & 8.8 & 9.3 & 8.1 & 12.3 & 6.6 & 6.5 & 6.3 & 12.2 & 3.0 & 2.6 & 2.2 & 14.1 & 4.0 & 3.5 & 2.7 \\
\hline Kielce & 13.1 & 2.0 & 1.9 & 2.3 & 14.7 & 2.9 & 3.3 & 3.1 & 11.5 & 2.3 & 1.8 & 1.7 & 12.6 & 3.5 & 3.2 & 3.7 \\
\hline Kraków & 7.0 & 3.7 & 3.7 & 3.1 & 6.6 & 3.1 & 2.6 & 3.2 & 7.7 & 2.7 & 2.6 & 3.2 & 6.3 & 2.5 & 2.4 & 2.8 \\
\hline Lublin & 11.7 & 2.0 & 1.5 & 1.0 & 13.1 & 3.8 & 3.8 & 2.6 & 10.3 & 0.9 & 0.8 & 0.7 & 13.9 & 2.9 & 2.4 & 2.2 \\
\hline Łódź & 8.9 & 2.8 & 2.9 & 2.1 & 11.5 & 4.2 & 3.9 & 4.6 & 10.9 & 5.9 & 5.6 & 5.3 & 14.1 & 3.9 & 4.2 & 4.4 \\
\hline Olsztyn & 4.9 & 4.0 & 2.9 & 0.9 & 15.8 & 5.4 & 4.8 & 4.8 & 8.2 & 1.3 & 1.4 & 1.3 & 8.2 & 2.2 & 2.4 & 2.6 \\
\hline Opole & 4.2 & 4.7 & 5.4 & 0.1 & 10.4 & 11.6 & 8.9 & 2.5 & 2.5 & 2.6 & 2.8 & 3.5 & 3.2 & 3.3 & 3.1 & 2.6 \\
\hline Poznań & 15 & 8.4 & 9.5 & 7.5 & 8.5 & 9.5 & 10.1 & 9.3 & 3.9 & 2.5 & 2.4 & 1.5 & 6.9 & 2.9 & 2.8 & 2.6 \\
\hline Rzeszów & 9.3 & 5.5 & 3.4 & 4.0 & 10.7 & 5.2 & 4.5 & 2.7 & 9.4 & 2.0 & 2.1 & 1.6 & 10.8 & 4.4 & 2.9 & 1.8 \\
\hline Szczecin & 10.7 & 2.4 & 1.3 & 0.6 & 11.4 & 3.7 & 1.8 & 2.0 & 9.1 & 3.3 & 3.1 & 2.8 & 10.4 & 4.9 & 4.2 & 3.1 \\
\hline Wrocław & 8.7 & 7.9 & 2.2 & 1.6 & 13.1 & 5.7 & 3.4 & 3.8 & 6.5 & 2.9 & 2.4 & 1.9 & 6.9 & 3.7 & 4.1 & 4.0 \\
\hline Zielona G. & 9.8 & 2.3 & 1.9 & 1.2 & 11.2 & 2.9 & 2.1 & 1.3 & 10.4 & 2.7 & 2.4 & 1.2 & 11.3 & 2.7 & 2.5 & 1.9 \\
\hline
\end{tabular}

Source: own calculations.

Based on the values of these coefficients, it is possible to recognize that in Wrockaw a convergence occurred between mean transaction prices in the primary and secondary markets. By analyzing the formation of mean offer prices in the primary and secondary markets, it is possible to recognize that in the first part of the studied time period (until Q4 2008) there was a divergence of prices, and in the second part, a convergence of mean prices occurred. By evaluating the formation of transaction and offer prices in the primary market it seems possible to state that a convergence occurred until Q2 2009, followed by a divergence of prices. It is not possible to notice any long-term relationships (neither a convergence nor a divergence) in the development of mean transaction and offer prices in the secondary market.

An analogous analysis was conducted for the remaining cities. In Białystok it was shown that, among other things, a weak divergence existed (until Q4, 2009), and then a convergence in mean transaction prices in the primary market and the mean transaction price in the secondary market. In Bydgoszcz, among other things, a divergence between mean transaction prices in the primary and secondary markets was observed. Gdańsk was characterized by, among other things, a period of divergence of transaction and offer prices in the secondary market (from Q4, 2007) and a convergence of mean transaction prices in the primary and secondary markets (from Q4, 2006 until Q2, 2011). In Katowice, it was identified that, among other things, a divergence first existed (until Q2, 2010) and then a convergence of mean transaction and offer prices in the primary market, and that there was also a convergence and stabilization of mean transaction prices in the primary and secondary markets. Kraków featured a period of divergence (Q4, 2006 - Q3, 2008) and next a convergence of mean transaction prices in the primary and secondary markets. In Łódź, a period of convergence (Q4, 2006 $\mathrm{Q} 2,2008)$ was observed, and then a divergence of mean offer prices in the primary and secondary markets. In Olsztyn, a clear convergence of mean transaction and offer prices in the primary market was noted (Q1, 2007 - Q3, 2011) and a convergence (in 2007) and then, a stabilization of the relationship between mean transaction and offer prices in the secondary market. Rzeszów was characterized by, among other things, a convergence of mean transaction and offer prices in the secondary market. In Szczecin, an initial period of convergence (Q1, 2007 - Q3, 2009) was observed, followed by a period of slight divergence of mean transaction and offer prices in the secondary market. In Warsaw, a period of significant divergence (until Q3, 2009) was noted, and next a period of convergence $(Q 4,2009$ - Q4, 2010) of mean transaction and offer prices in the primary market took 
place. In Zielona Góra, among other things, a period of convergence of mean transaction and offer prices in the primary market (from Q3, 2007) was observed as well as a convergence (Q3, 2007 - Q1, 2009) and then a stabilization of the mean offer price in the primary and secondary markets.

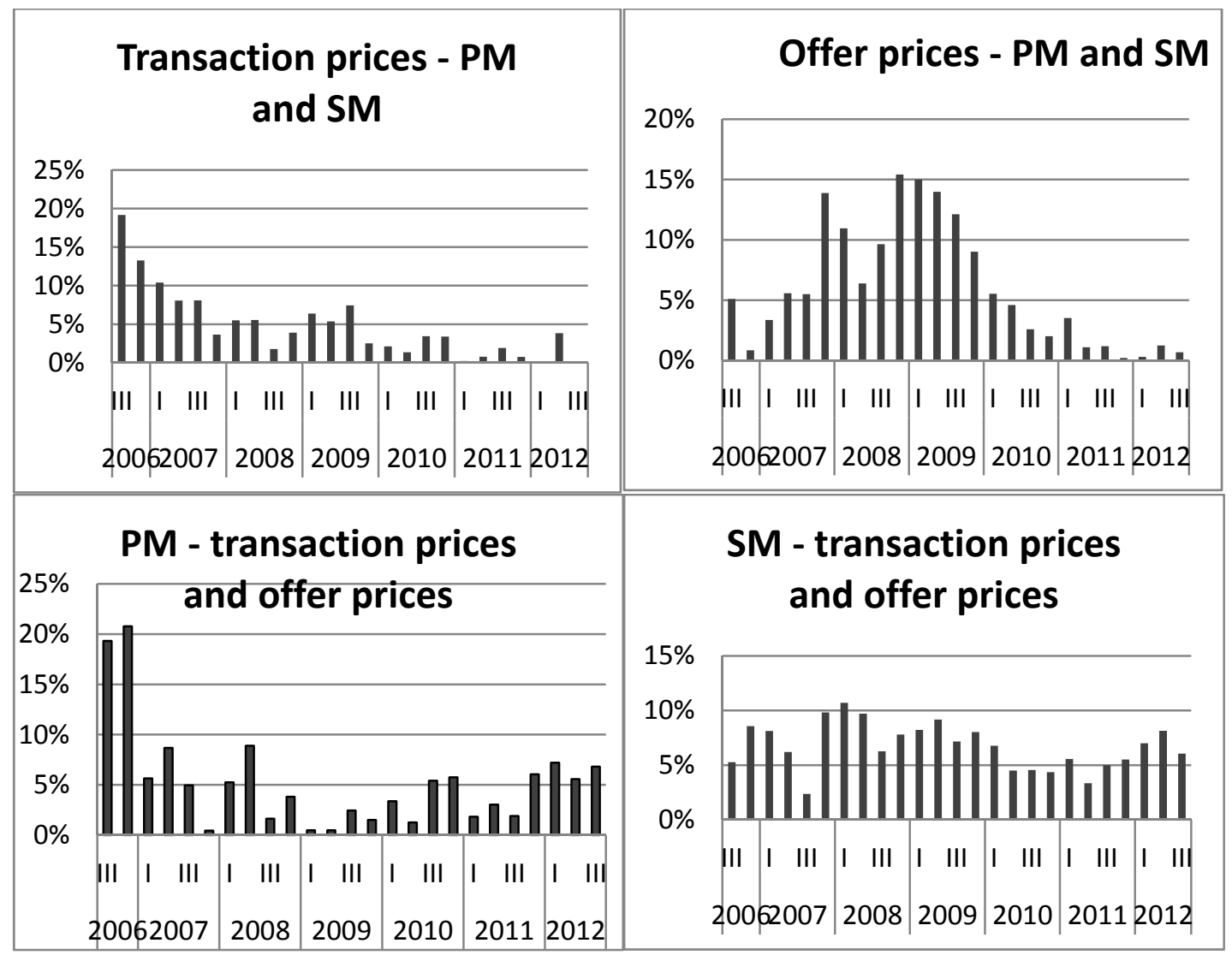

Fig. 3. Variability coefficients for mean prices in Wrocław. Source: own work.

\section{Conclusions}

The results of this study concerning the formation of mean offer and transaction prices in the primary and secondary markets in 16 cities in Poland show that:

1) In the majority of studied cities, prices in the primary market were more dynamic than in the secondary market,

2) in the majority of studied cities, transaction prices were more dynamic than offer prices,

3) a statistically significant correlation existed between the studied price categories in the entire studied time period and the majority of its subintervals,

4) generally, the variability of transaction and offered prices in both market segments decreased over time and

5) in some of the studied cities, a convergence and divergence of mean prices in different segments of the residential market, different price categories and different time periods existed.

This research does not take into account all of the issues connected with the development of prices in local real estate markets in Poland. One such issue that is important for the investor is the question of price forecasting. This is the subject of research the partial results of which have been included in other papers (Dittmann 2012, Dittmann 2013b).

\section{Literature}

AUGUSTYNIAK H., ŁASZEK J., OlSZEWSKI K., 2012 Modelowanie cykli na rynku nieruchomości mieszkaniowych - uwzględnienie interakcji pomiędzy rynkiem pierwotnym a wtórnym i efekty mnożnikowe w: Raport o sytuacji na rynku nieruchomości mieszkaniowych i komercyjnych w Polsce w 2011r. NBP (www. nbp.pl).

Baza cen nieruchomości mieszkaniowych NBP, www.nbp.pl (dostęp z dnia 20.11.2012).

BALDOWSKA G., LESZCZYŃSKI R., MYSZKOWSKA B., 2012 Tendencje rozwoju rynków lokalnych (analiza 
porównawcza 16 miast $w$ Polsce $\mathrm{w}$ : Raport o sytuacji na rynku nieruchomości mieszkaniowych $i$ komercyjnych $w$ Polsce $w$ 2011r. NBP (www. nbp.pl).

BEŁEJ M., 2012, Dynamika zmian cen nieruchomości w aspekcie teorii przejść nieciagtych, Studia i Materiały Towarzystwa Naukowego Nieruchomości, vol. 20 nr 1, Olsztyn.

BRYX M., 2008, Rynek nieruchomości : system i funkcjonowanie, Poltext, Warszawa.

DĄBROWSKI J., 2009, Zastosowanie metod i algorytmów statystycznych do wyznaczenia parametrów globalnych dla potrzeb badania rynku i wyceny nieruchomości, Studia i Materiały Towarzystwa Naukowego Nieruchomości, vol. 17 nr 1, Olsztyn.

DĄBROWSKI J., 2011, Modele regresji liniowej z czynnikiem autokorelacji w analizie rynku nieruchomości, Studia i Materiały Towarzystwa Naukowego Nieruchomości, vol. $19 \mathrm{nr}$ 1, Olsztyn.

DitTMAnN I., 2012, Prognozowanie cen na lokahnych rynkach nieruchomości mieszkaniowych na podstawie analogii przestrzenno - czasowych, Ekonometria Econometrics nr 4 (38), Wydawnictwo Uniwersytetu Ekonomicznego we Wrocławiu.

DiTTMANN I., 2013a, Ceny ofertowe i transakcyjne na wybranych rynkach mieszkaniowych w Polsce w: Metody $i$ modele $w$ rozwoju regionów. Problemy społeczno - ekonomiczne w uwarunkowaniach ryzyka, Wydawnictwo Uniwersytetu Ekonomicznego w Katowicach, Katowice (w druku).

DiTTMANN I., 2013b, Forecast accuracy and similarities in the development of mean transaction prices on Polish residential markets, Ekonometria Econometrics nr 1 (39), Wydawnictwo Uniwersytetu Ekonomicznego we Wrocławiu.

FORYŚ I., 2011, Społeczno - gospodarcze determinanty rozwoju rynku mieszkaniowego w Polsce. Ujęcie ilościowe, Wydawnictwo Naukowe Uniwersytetu Szczecińskiego, Szczecin.

GDAKOWICZ A. HOZER J. 2012, Analiza rozwoju rynków nieruchomości mieszkaniowych w wybranych miastach Polski z zastosowaniem metod taksonomicznych, Studia i Materiały Towarzystwa Naukowego Nieruchomości, vol. 20 nr 1, Olsztyn.

KUCHARSKA - STASIAK E., 2012, Nieruchomość w gospodarce rynkowej, Wydawnictwo Naukowe PWN, Warszawa.

NYKIEL L., 2011, Demograficzne uwarunkowania rozwoju mieszkalnictwa i rynku mieszkaniowego, Studia i Materiały Towarzystwa Naukowego Nieruchomości, vol. 19 nr 3, Olsztyn.

RENigier-BiŁOZOR M., 2011, Analysis of real estate markets with the use of the rough set theory, Studia i Materiały Towarzystwa Naukowego Nieruchomości, vol. 19 nr 1, Olsztyn.

TROJANEK R., 2012, Zmiany cen na wtórnym rynku mieszkaniowym w Poznaniu w latach 2008-2011, Studia i Materiały Towarzystwa Naukowego Nieruchomości, vol. 20 nr 1, Olsztyn.

TROJANEK R., 2011, Wpływ wahań koniunkturalnych na lokalne rynki mieszkaniowe, Studia i Materiały Towarzystwa Naukowego Nieruchomości, vol. 19 nr 1, Olsztyn.

ŻELAZOWSKI K., 2011, Regionalne zróżnicowanie cen i ich determinant na rynku mieszkaniowym w Polsce, Studia i Materiały Towarzystwa Naukowego Nieruchomości, vol. 19 nr 3, Olsztyn. 